\title{
Factors related to productivity and persistence of lucerne (Medicago sativa) genotypes with different fall dormancy levels: a review
}

\author{
Fatores relacionados à produtividade e perenidade de genótipos de alfafa (Medicago sativa) com \\ diferentes níveis de dormência: uma revisão \\ Factores relacionados con la productividad y longevidad de genotipos de alfalfa (Medicago sativa) \\ con diferentes niveles de latencia: una revisión
}

Received: 12/07/2021 | Reviewed: 12/13/2021 | Accept: 12/20/2021| Published: 01/03/2022

\author{
Sarah Maria Hoppen \\ ORCID: https://orcid.org/0000-0001-7531-8484 \\ Western Paraná State University, Brazil \\ E-mail: sarah.hoppen@hotmail.com \\ Marcela Abbado Neres \\ ORCID: https://orcid.org/0000-0003-3221-4030 \\ Western Paraná State University, Brazil \\ E-mail: mabaneres@gmail.com \\ Derrick Moot \\ ORCID: https://orcid.org/0000-0002-5691-4915 \\ Lincoln University, New Zealand \\ E-mail: moot.derrick@lincoln.ac.nz
}

\begin{abstract}
The lucerne productive and nutritional potential make it the most used forage legume worldwide. This wide use leads genetic improvement programs to increasingly select the main requirements for a given edaphoclimatic condition. However, in Brazil, the research on genetic improvement of lucerne has been limited over the years, which has hindered the production of this species and the domination of other legumes in animal production, as estilosantes and pigeon pea. This literature review aimed to present results from countries such as New Zealand and Australia that lead the world ranking, as weel as Argentina, in the cultivation of this crop and that can be used as showcase to understand the management of lucerne. From extensive bibliometry analyses in the period between 1963 and 2021, variables as persistence and phyllochron in these countries indicate that it is possible to produce lucerne with similar productivity, longevity and quality in Brazil. Nevertheless, to leverage this production, not only genetic improvement should be aimed, but also research and dissemination of knowledge on the ideal management of defoliation and, mainly, on the choice of the genotype and dormancy level to be cropped by the producer.
\end{abstract}

Keywords: Alfalfa; Forage canopy; Phenology; Persistence.

\section{Resumo}

O potencial produtivo e nutricional da alfafa faz dela a leguminosa forrageira mais utilizada no mundo todo. Esta ampla utilização conduz os programas de melhoramento genético a cada vez mais selecionar as principais necessidades para determinada condição edafoclimática. Contudo, no Brasil as pesquisas de melhoramento genético da alfafa foram limitadas ao longo dos anos, o que causou um entrave na produção desta espécie e a dominação de outras leguminosas na produção animal, tais como estilosantes e feijão-guandu. Esta revisão de literatura objetivou apresentar resultados de países como a Nova Zelândia e a Austrália que lideram o ranking mundial, assim como a Argentina, no cultivo desta espécie e que podem ser utilizadas como vitrines para se entender sobre manejo da alfafa. A partir de extensa análise de bibliografia de publicações no período de 1963 a 2021, variáveis como perenidade e filocrono nestes países indicam que é possível produzir alfafa com similar produtividade, longevidade e qualidade no Brasil. Contudo, para alavancar essa produção não somente o melhoramento genético deve ser visado, mas também pesquisa e disseminação do conhecimento sobre o manejo ideal de desfolhação e, principalmente, de escolha da cultivar e nível de dormência a ser cultivado pelo produtor.

Palavras-chave: Alfafa; Dossel forrageiro; Fenologia; Persistência.

\section{Resumen}

El potencial productivo y nutricional de la alfalfa la convierte en la leguminosa forrajera más utilizada a nivel mundial. Este amplio uso lleva a los programas de mejoramiento genético a seleccionar cada vez más las principales necesidades de una determinada condición edafoclimática. Sin embargo, en Brasil, la investigación sobre el 
mejoramiento genético de la alfalfa ha sido limitada a lo largo de los años, lo que ha obstaculizado la producción de esta especie y el dominio de otras leguminosas en la producción animal, como el estilo y el gandul. Esta revisión de la literatura tuvo como objetivo presentar resultados de países como Nueva Zelanda y Australia que lideran el ranking mundial, además de Argentina, en el cultivo de esta especie y que puedan ser utilizados como vitrinas para entender el manejo de la alfalfa. A partir de extensos análisis bibliométricos en el período comprendido entre 1963 y 2021 , variables como perennidad y filocrón en estos países indican que es posible producir alfalfa con similar productividad, longevidad y calidad en Brasil. Sin embargo, para apalancar esta producción, no solo se debe apuntar al mejoramiento genético, sino también a la investigación y difusión del conocimiento sobre el manejo ideal de la defoliación y, principalmente, sobre la elección del cultivar y nivel de latencia a cultivar por parte del productor.

Palabras clave: Alfafa; Dossel forrajero; Fenología; Persistencia.

\section{Introduction}

The lucerne, or alfalfa (Medicago sativa), is the most used legume in the world due to its high yield potential and adaptability under different water availability, soil, temperature, photoperiod and management conditions. This plant belongs to the Fabaceae family, subfamily Papilionoideae (Rassini, 1999). Originally from the Caucasus region, which covers Turkey and Iran, it was spread in Europe and Asia before the Roman Empire and then to America and Australasia (Bouton, 2012). It is believed that lucerne is cropped in about 32 million hectares worldwide (Brummer, 2004), mainly in the United States of America (USA), Canada, France, China, Argentina and Australia (Veronesi et al., 2010). Lucerne can be cropped for hay, silage, pellets and fresh forage in monoculture (Moot et al., 2012) or intercropped with other species, as chicory and canola (Craig et al., 2013).

In the New Zealand the area of lucerne has increased in the past 30 years mainly in rainfed areas where its deep tap roots allow it to access water deeper in the profile than grasses (Brown et al., 2005; Moot, 2021) and through the development of genotypes with pest and diseases resistant (Harvey et al., 2014). Characterized by the temperate climate, the east coast of South Island has a mean rainfall of $50 \mathrm{~mm} / \mathrm{month}$, well distributed all year but evapotranspiration exceed rainfall every summer (Radcliffe \& Baars, 1987). It means that plants are required to be adapted to dryness in the most productive seasons. The high spring growth rates of high quality (energy and protein) vegetative lucerne match sheep lambing, and the need for high lamb growth rates before slaughter in December (Brown et al., 2005).

More than $12000 \mathrm{~km}$ away, in Brazil, the intensification of dairy production has increased the lucerne cultivation in South and Southern regions, where this legume is more utilized as hay than pasture due to its ease in storage and transport (Vilela et al., 2008). It is believed that the introduction of lucerne in Brazil happened in mid-1850, in the South region, mainly in the Rio Grande do Sul state by its proximity with Uruguay and Argentina (Saibro, 1985). In 1990 the research institutes from the Southeast region started investigations to recommend appropriate genotypes in different environments. However, the high costs of seed importation from Argentina, Chile and the USA reduced the species cultivation liability. Nowadays, the most common genotype in Brazil is the cv. "Crioula", a hybrid selected for high adaptability, shoot and crude protein yields in subtropical and tropical conditions (Botrel et al., 2001).

An important barrier in Brazilian lucerne yield is the high sensibility of this species to the high aluminium (Al) levels in Brazilian soils, found in the main production areas. Some researchers have presented improvements on Al tolerance, by genetic breeding between, for example, genotypes "São José do Inhaporá" and "Porto Alegre” (Ávila et al., 2019). These genotypes presented deeper roots in greenhouses, which suggest a greater ability to search for water and nutrients even under Al stress situations.

According to Basigalup and Ustarroz (2007) in Brazil, seasonality has been considered another great barrier to lucerne management because some genotypes reduce their activity through environmental and physiological situations. But, according to some authors, this process is essential to improve the persistence and shoot yield over the years (Hoppen et al., 2019; Teixeira et al., 2015), and they differ in intensity and persistence with fall dormancy levels. 
This literature review approaches several aspects related to 1. Lucerne shoot yield and persistence, such as genotypes, defoliation frequency, below-ground development and canopy structure, 2. The resilience of this species to different environments and conditions, and 3. The need to improve on Brazilian lucerne genetic programs to optimize land, solar radiation and nutrients.

\section{Methodology}

The analyses were performed by bibliometry from databases related to lucerne persistence on temperate climates, root organic components storage and physiology, impact of genotype on aerial tissue plasticity after different defoliation frequencies, interaction between incident radiation and leaf area index/leaf area angle, and organic component mobilization. The period analyzed was from 1963 to 2021, that totalized 68 papers including articles and thesis, analyzed for strength, weakness, opportunities and threats (SWOT) (Benzaghata et al 2021). The main databases used for this research were Elsevier.com, ResearchGate.net, Onlinelibrary.wiley.com and Scielo.br

\section{Fall Dormancy (FD)}

Dormancy is a physiological process in response to the environment. Commonly observed in seeds, this process also occurs in other phases of a plant's life cycle to avoid the losses of energy over extreme situations related to temperature, osmosis, photoperiod, pH and water conditions (Seppänen et al., 2018). Characterized by the reduction of metabolic activities, the dormancy in the vegetative stage is regulated by the hormones abscisic acid (ABA), indole-3-acetic acid (IAA) and gibberellin $\left(\mathrm{GA}_{3}\right)$, which are responsible for cellular division; stomata closure and photosynthesis reduction; regrowth and flowering, respectively. The regular level of each hormone is related to the dormancy level and specific function, though the control is not well known by the geneticists (Li et al., 2015). Han et al. (2011) found that non-dormant lucerne presented greater concentrations of $\mathrm{GA}_{3}$ and IAA and lower concentrations of $\mathrm{ABA}$.

The high genetic variability in fall dormancy means lucerne is adapted to different environmental conditions (Fédière et al., 2003; Teixeira et al., 2007a) and has resulted in a diversity of cultivars and impacted on economic characteristics as high feed yield of excellent nutritional value and persistence (Brown, Moot \& Pollock, 2005). To classify all lucerne genotypes, a ranking was created based on the response of seedling crops to grow in autumn after being sown in spring. According to Barnes et al. (1979), plants that stop stem extension over the cold seasons are classified as FD1-3, plants that present some yield but are still susceptible to dormancy are classified as FD4-6, and plants that present regular development over the cold seasons are ranked as FD7-9. Some authors also include the FD10-11 classifications, as highly non-dormant plants (Brummer et al., 2000).

To identify the dormancy level of each genotype it is necessary to evaluate its growth when exposed to lower photoperiod and temperature as a response to $\mathrm{GA}_{3}$. Plants classified as non-dormant usually are taller than the dormant ones (Cunningham et al., 2001; Haagenson et al., 2003), as an effect of higher concentration of IAA, responsible for phototropism (Han et al., 2011; Liu et al., 2016), but this difference is applied on greater internode length, once the number of leaves does not differ from dormant ones (Hung et al., 2016).

\section{Perennial Organic Components Storage}

Over the dormancy period, which depending on genotype and climate can range from mid-autumn to early spring (Clark et al., 2019), the plants restrain their aerial production and focus on perennial storage. This process allows the plants to fully regrow over the spring (Teixeira et al., 2015) by remobilizing the perennial components (carbon and nitrogen) to aerial 
regrowth. It enables a maximum light interception when temperatures are higher in spring and summer. As a perennial plant, when in constant storage stress, lucerne can gradually reduce this regrowth ability, which leads to a reduction in persistence (Hoppen et al., 2019). The crown and roots of lucerne are the storage organs from which remobilization occur. These organs develop in stable canopies, provided the nutritional demands from aerial portions. Too frequent defoliation can cause a reduction in perennial reserves through a regrowth season (Rimi et al., 2014; Moot et al. 2021), then there is a need to balance root and shoot growth over a season (Moot et al., 2012; Teixeira et al., 2007b).

The perennial yield dynamic is linear, with the simultaneous growth of both portions (roots and crowns), but differences in their proportions according to the plant development (Teixeira et al., 2007), nutrition, water status and genotype (Pembletom, Cunningham \& Volenec, 2010). The proportion of root structure, formed by organic reserves, structural fibres and water, differs with defoliation frequency (Teixeira et al., 2007; Moot et al. 2021), dormancy level (Pembletom et al., 2010; García et al., 2021), soil fertility, water availability and plant age. The temperature and photoperiod reduction can activate a more expressive partitioning of storage components to perennial organs (Seppänen et al., 2018). Teixeira, Moot and Brown (2008) reported that there was a constant flux on assimilates to roots in autumn, but a maximum of carbon (C) and nitrogen (N) partitioning through mid-summer when there is a greater photosynthesis rate due to temperature and radiation.

In well-irrigated situations with forage canopy over the whole productive season, once the crops reach $\sim 95 \%$ of light interception (LI), there is the intense partitioning of organic components to perennial organs (Teixeira et al., 2007b). These reserves can be mobilized to aerial regrowth after defoliation and serve as an energy bank to regrow in low metabolic activity situations, as dormancy. According to Haangerson et al. (2003) and Cunningham et al. (2001), the correlation between dormancy and soluble sugars storage is positive, which means that the more dormant the plant, the greater its competence to store soluble sugars and $\mathrm{N}$ and, consequently, a greater capacity to survive over the winter.

The component storage index differs according to its function. Soluble sugars present a sharper fluctuation in their concentration over the year, because they represent the primary source of energy to plants, and have high mobilization between the above-below ground organs (Cunningham \& Volenec, 1997; Teixeira et al., 2007b). It makes the soluble sugars more sensitive to dormancy regulation and regrowth requirements. Rimi et al. (2014) found greater concentration and content of water-soluble carbohydrates (WSC) in taproots compared to crowns, which ranged from 302.0 to $148.4 \mathrm{mg} \mathrm{plant}^{-1}$ in midautumn, respectively.

Although the mechanisms on soluble sugar storage control vary according to fall dormancy level (Liu et al., 2016; Xu et al., 2020), the whole perennial sugar storage is unaffected (Pembletom et al., 2010). Rimi et al. (2014) obtained a considered fluctuation of sugar concentrations over the years, with lower values of non-dormant genotypes over the winter (taproot). However, Xu et al. (2020) found a greater yield of soluble sugar in FD6 genotypes ( $\sim 25 \mu \mathrm{g} \mathrm{mg}^{-1}$ of fresh weight) than in FD2 genotypes ( $\sim 20 \mu \mathrm{g} \mathrm{mg}^{-1}$ of fresh weight). These contrasts support the environmental effects on perennial dynamics (Mitchell et al., 2020).

The mechanism of carbohydrates utilization is related to perennial organs respiration. There is an estimation of $\sim 83 \%$ of ${ }^{13} \mathrm{C}$ loss with root-respiration in the 30 days after defoliation that works as the energy supply to each cell individually, which increases the survival index in extreme winters. From the remaining root ${ }^{13} \mathrm{C}$, it was estimated that only $13 \%$ were used on plant regrowth (Avice et al., 1996).

The starch tends to maintain a regular concentration in perennial organs, with a greater quantity in long regrowth cycles (Mitchell et al., 2020). Pembletom, Cunningham and Volenec (2010) found differences in perennial starch production of 'DuPuits' (FD2, $288 \mathrm{mg} \mathrm{g}^{-1}$ ) and 'Grassland Kaituna' (FD5, $288 \mathrm{mg} \mathrm{g}^{-1}$ ) to 'Sardi 7' (FD10, $252 \mathrm{mg} \mathrm{g}^{-1}$ ) cultivars. And Yang (2020) showed faster partitioning to root in FD2 genotype (1.5 from 0 to $250{ }^{\circ} \mathrm{Cd}$, and then 0 at $300{ }^{\circ} \mathrm{Cd}$ ) compared to $\mathrm{FD} 10$ 
(1.5 from 500 to $550{ }^{\circ} \mathrm{Cd}$, and then to 0 after that), which means that FD2 genotypes can be defoliated at a greater frequency than FD10, to express similar performance.

The amount of starch storage is affected by the defoliation frequency. Very frequent defoliation (DF 28 days) led to maximum and minimum storage supplies of $15 \%$ and $3 \%$ of DM, whereas a DF 42 days improved it to $30 \%$ and $11 \%$ of DM, respectively (Teixeira et al., 2007). Both the quantity and dynamics of partitioning are affected by the frequency of defoliation. These authors showed superior partitioning of starch to shoots during spring in DF 28 while the DF 42 plants were improving the starch storage in roots at the same time. These results illustrate partitioning to shoots in preference to roots when a $\mathrm{C}$ shortage is being created by frequent defoliation (Moot et al., 2021). It limits the ability of the plant to restore root reserves under frequent defoliation.

The $\mathrm{N}$ storage on the perennial system also appears to be positively related to fall dormancy and winter survival, with no apparent tendency in reduction over the years (Gramshaw et al.; Cunningham et al., 2001). The effects of defoliation frequency on N concentration were presented by Teixeira, Moot and Mickelbart (2007) in cv. "Grassland Kaituna", with a variation of $0.9 \%$ and $1.8 \%$ in perennial dry matter (DM). The authors also presented an abrupt reduction of $\mathrm{N}$ concentration after the change of defoliation frequencies, from 42 to 28 days. But with the same fluctuation pattern over the seasons in both defoliation regimes, which suggests that, besides the defoliation frequency, the $\mathrm{N}$ reserves mobilization was modulated by external factors, such as temperature and photoperiod (Gramshaw et al., 1993; Teixeira et al., 2007b), and plant water availability (Pembletom et al., 2010; Luo et al., 2019).

However, some authors agree that more than the dormancy level, the main characteristic that impacts shoot yield and lucerne persistency is the defoliation frequency (Ventroni et al., 2010; Rimi et al., 2014).

\section{Defoliation Frequency (DF)}

Historically, the lucerne fields were recommended to be defoliated at 10-20\% of flowering, as an indicator of the balance between shoot yield and root growth. In tropical areas, the defoliation over the cold season is also indicated to happen when the basal shoot presents 3-5 cm (Rassini et al., 2015). But these systems do not take into account the nutritive value of this pasture. There is an increase in weight due to flowering that reduces the digestibility of DM. According to Tabacco et al. (2002), there are three forms to produce high-quality forage, 1. Increase the defoliation frequency, 2. Increase the output height, and 3. Select the most nutritional genotype. Nevertheless, even the most nutritional genotype has its digestibility reduced by the increase of hard stems, which means that the main nutritional controller is the total yield of foliage (Ta et al., 2020).

In animal production, the advocacy of nutritional quality leads to higher defoliation frequencies, with earlier plant harvest that aims greater leaf:stem ratio, lower fibre content and high crude protein (CP) yield (Kallembach et al., 2002; Tabacco et al., 2002). However, these plants end up presenting lower shoot yield than early-flowering harvested canopies (Gramshaw et al., 1993) and may not attend the animal requirements.

Within the scope of plant physiology and crop persistency, the increase of defoliation frequency reduces the perennial biomass by the high demand of organic components to new tissue regrowth (Teixeira et al., 2007a), which reflects on regrowth potential (Brown et al., 2006) and impacts negatively on plant survival (Ventroni et al., 2010). However, the accelerated senescence process means that a canopy defoliated after the $10 \%$ of flowering presents a lower stocking rate, which reduces performance compared with canopies defoliated before flowering (Berone et al., 2020).

There are cases with no differences in crop persistence between long and short regrowth cycles (Chen et al., 2013), which creates the debate between defoliation frequency and dormancy levels as the main point of impact of a sustainable 
canopy. Yet, it is common agreement that there is a need to find the balance between genotype and management for each situation to optimize the animal production and maintain stand persistence.

\section{Shoot Yield}

The shoot yield ( $\left.\mathrm{DM} \mathrm{ha}{ }^{-1}\right)$ is the variable with the preeminent impact on farmers as the most sensitive characteristic, which aggregates the plant community to describe canopy efficiency and nutritional value. A lucerne field in ideal conditions can yield over $20 \mathrm{t} \mathrm{DM} \mathrm{ha}^{-1}$ (Brown et al., 2005; Teixeira et al., 2007b) in temperate conditions. The yield is influenced directly by the canopy characteristics, such as shoot density and individual shoot mass (ISM) (Maamoury et al., 2017) (Figure 1). These are, in turn, influenced by temperature, photoperiod (Ta et al., 2020), irrigation (Gramshaw et al., 1993), plant age, harvest management (Ventroni et al., 2010), dormancy level (Harvey et al., 2014), soil fertility (Lemaire et al., 2019), etc.

Figure 1. Canopy characteristics action on shoot yield.

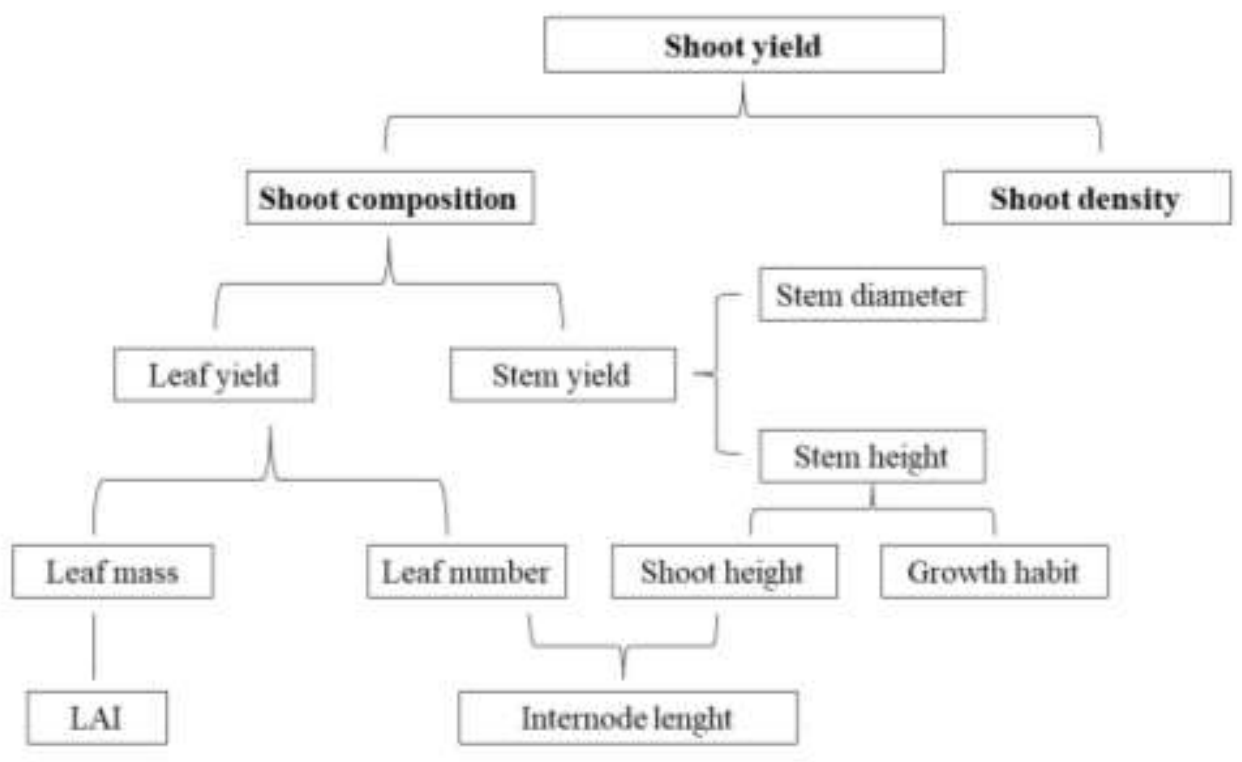

LAI: leaf area index. Source: Adapted from Maamouri et al. (2017).

According to Weller (1987), the plant population of vegetative canopies and consequently shoot density, in the absence of negative external influences (as diseases and pests), are regulated by competition for light and nutrients. This process is called self-thinning and has a constant value of $-3 / 2(-1.5)$ suggested by Yoda (1963) as the relationship between the log of plant weight and the log of plant density. It means that plants in constant competition kill the smaller plants, so those remaining can increase the size/density by the new shoots production and/or increase of ISM.

Based on this principle, a canopy in competition has a reduction in LI and need to elevate the new leaves to a higher horizon, where the light is more plentiful. This process is associated with $\mathrm{C}$ and $\mathrm{N}$ absorption of shaded tissues, and with the emergency of the new shoot to meet the plant requirements. A consequence is the increase of fibre and decrease of nutritional value and reduction of LAI as yield increases (Ta et al. 2020). This process is known as "increasing dry matter cost" (Lemaire et al., 2019), so the leaf:stem ratio is also affected. Lemaire et al. (1989) classified this process as age-related changes, a predictable and inevitable process. The key is the break of this natural process by defoliation and guarantee that such negative effects are reduced to the maximum. 
Over time, both processes will result in canopy collapse, characterized by the plant population reduction and lower shoot yield, associated with weed invasion and diseases. Ironically, in this scenario with a lower plant population, the plants individually are free of competition and present a higher LAI and leaf:stem ratio (Lemaire et al., 2019). However, it is not enough to compensate for the yield reduction when compared to a well-formed canopy.

The defoliation frequency is a plasticity regulator. Fields with short regrowth cycles produce shorter shoots, but in greater density, whereas fields cropped for hay production, for example, with long regrowth cycles present heavier and higher shoots, but in lower densities (Lemaire \& Chapman, 1996). Ventroni, Volenec and Cangiano (2010) presented significant interactions between defoliation frequency and fall dormancy, where the dormant plants (FD3) had greater regrowth potential when in DF 20 days (approximately 500 shoots $\mathrm{m}^{-2}$ ), while in DF 30 and DF 40 this dormancy level had greater shoot height. But it was also reported that the FD3 shoots at DF 20 were smaller and lighter, which resulted in lower shoot yield.

The greater canopy area produces greater photosynthetic activity from tissues, so its removal represents an energetic deficit to the plant. It then initiates $\mathrm{C}$ and $\mathrm{N}$ remobilization from perennial tissues to new shoots for regrowth to increase aerial biomass, to finally re-establish the energy balance (Lemaire \& Agnusdei, 2000). It causes a sigmoid curve on shoot regrowth (Moraes \& Palhano, 2002) that represents the initial delay on linear growth rate (LGR), followed by a period when the above ground mass is rapidly increasing until a ceiling phase when aerial biomass production is equal to maintenance respiration requirements and partitioning to perennial organs.

The increasing slope on LGR curves is affected by defoliation frequency, storage reserves (Teixeira et al., 2007a), and temperature (Yang et al., 2021). Linear growth rates have shown a range from 18.1 to $206 \mathrm{~kg} \mathrm{DM} \mathrm{ha}^{-1} \mathrm{~d}^{-1}$ when the mean air temperature increased from 0 to $15.2{ }^{\circ} \mathrm{C}$ and then to $22.2^{\circ} \mathrm{C}$ (plateau phase). The authors also indicate a variation on maximum LGR according to photoperiod regime, with a possible reduction of $30.1 \mathrm{~kg} \mathrm{DM} \mathrm{ha}^{-1} \mathrm{~d}^{-1}$ from increasing to decreasing photoperiod, with no differences in the rate, but on maximum LGR $\left(\sim 149 \mathrm{~kg} \mathrm{DM} \mathrm{ha}^{-1} \mathrm{~d}^{-1}\right)$.

\section{Phenological Characteristics}

The shoot yield is the result of the quantity of light absorbed, or photosynthetically active radiation absorbed $\left(\mathrm{PAR}_{\mathrm{i}}\right)$ and the radiation use efficiency (RUE) to convert this light into biomass (Brown, Moot \& Teixeira, 2006; Teixeira et al., 2007a; Jaurégui et al., 2019). The quantity of PAR $\mathrm{P}_{\mathrm{i}}$ is regulated by LAI that, in lucerne, has a critical point (LAI $\mathrm{L}_{\text {critical }}$ ) of 3.2 to $3.6 \mathrm{~m}^{2} \mathrm{~m}^{-2}$ (Teixeira et al., 2007a). This $\mathrm{LAI}_{\text {critical }}$ represents the maximum absorption potential of PAR by the canopy. When the canopy LAI is below, this potential is not realized, but at higher LAI there is loss of lower leaves from senescence (Costa et al., 2011). When the critical LAI is achieved by the canopy, plants activate the C mobilization to shadowed tissues and perennial organs (Lemaire \& Chapman, 1996), estimated to be at $90 \%$ of LI, though more recent studies have reported to be between $93-95 \%$ of LI (Teixeira et al., 2007b).

The LAI is a morphological characteristic that resulted from three main factors, leaf appearance rate (LAR), leaf area expansion rate (LER) and leaf live spam (LLS), that act on leaf size, shoot density and number of leaves per shoot, all are related to accumulated thermal-time, photoperiod, N, irrigation, etc. (Lemaire \& Chapman, 1996). The LLS is a genetic constant, though all the morphogenetic characteristics are affected by abiotic factors.

\subsection{Leaf Appearance Rate (LAR) and Phyllochron}

The LAR (number of primary leaves ${ }^{\circ} \mathrm{Cd}^{-1}$ ) is the main factor that acts on LAI and is regulated directly by temperature (Teixeira et al., 2007b; Baldissera et al., 2014) and incident radiation (Gastal \& Lemaire, 2015). It is opposite to phyllochron $\left({ }^{\circ} \mathrm{Cd}\right.$ per primary leaf), which indicates the thermal-time requirement to develop a new leaf. 
In lucerne, the leaves are morphologically separated between primary and axillary. It represents the aerial distribution of each plant. The distance between nodes and their position also influences the number of axillary leaves, with lower axillary leaf numbers and branching further up the main stem (Baldissera et al., 2014), a characteristic correlated to photoperiod (Jáuregui et al., 2019).

Initially, it was considered that the most frequent defoliation acts negatively on LAI, once the more photosynthetic active zone removal could increase the phyllochron (Lemaire \& Chapman, 1996). However, this process may result in benefits, as a greater light exposure to lower horizons reduces the leaf senescence; stimulate the branching and the appearance of new shoots (Gastal \& Lemaire, 2015). Mattera et al. (2013) obtained an increase in LAI with a longer distance between seeding rows due to light in the canopy basal regions. Similarly, Teixeira et al. (2007b) found an increase of phyllochron with the photoperiod reduction, which reinforces the high relationship between incident radiation and LAR.

Another factor that acts on LAR is plant age. Comparing the establishment phase with the subsequent year, Baldissera et al. (2014) presented an increase of LAR with the increase of regrowth cycle number. This process occurs due to the generation of new tissues to perennial organs at the establishment phase (Ta, Teixeira \& Moot, 2016). But, with the need for leaf expansion to achieve the ideal LAI, the plant mobilizes part of its energy from LAR to LAER (Gastal \& Lemaire, 2015).

\subsection{Leaf area expansion rate (LAER)}

Contrastingly of LAR, the LAER $\left(\mathrm{m}^{2} \mathrm{~m}^{-2}{ }^{\circ} \mathrm{Cd}^{-1}\right)$ is $\mathrm{N}$ reserves regulated, which are affected by defoliation as the main external factor (Teixeira et al., 2007b), that also affects the LAI and LI. After defoliation, there is a rapid increase of LAER of remaining leaves, since this process has an energetic lower cost compared to LAR. Although, in high-intensity defoliation frequency, with no remaining leaves, there is the requirement of reserves remobilization to produce new leaves, which impacts directly on perennial reserves and LAER (Gastal \& Lemaire, 2015).

The LAER, though being a natural response of the plant, must be considered a response to LAR that works as a proportional and analogue variable that achieves the leaf area requirement to maintain yield (Baldissera et al., 2014). To confirm the work by Lemaire and Chapman (1996) about how morphogenetic components act on LAI, Brown et al. (2005) added the plant population as the main factor that contributed to this variation. The authors indicate that photoperiod is the main agent of LAER as the plant is in a decreasing photoperiod the LAER decreases so LI is reduced.

Ta et a. (2016) reported differences among dormancy levels on leaves arrangements of seedling crops. The FD10 genotype produced heavier leaves than FD2 and FD5. The result was FD10 as the greatest shoot yield due to the greatest LI, a process modulated by differences of LAER among dormancy levels. Teixeira et al. (2007b) pointed the high defoliation frequency acts negatively on LAER. The authors explain the nutrients high demand by regrowth, and mainly in short regrowth cycles to plants to achieve the $\mathrm{LAI}_{\text {critical }}$ exhaust the organic reserves of plants and lead to population collapse.

\section{Solar Radiation}

The PAR comprises the waves length between 400 and $700 \mathrm{~nm}$ (Liang et al., 2014), which coincides with about 50\% of all incident radiation on the canopy. As incident radiation dependent, the PAR may also vary according to zenith angle, day length and climatic conditions (diffuse light) (França et al., 1997; Radin et al., 2003), besides the canopy conditions as the number of green leaves and chlorophyll leaf concentration (SPAD).

The $\mathrm{PAR}_{\mathrm{i}}$ is associated with shoot yield by RUE (g DM MJ PAR ${ }^{-1}$ ), split into an aerial portion (RUE $\mathrm{R}_{\text {shoot }}$ ) and total $\left(\mathrm{RUE}_{\text {total }}\right)$. After the defoliation, for example, when the plant has no leaf area, there is a need for organic reserves remobilization from perennial reserves to the aerial portion $\left(\mathrm{P}_{\text {shoot }}\right)$ (Moraes \& Palhano, 2002). It reduces root reserves but 


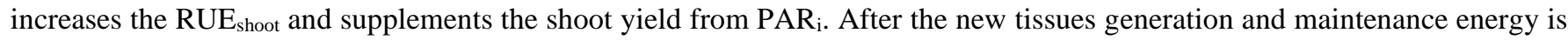
supplied, the plant enters a reproductive phase and then partitions carbon and nitrogen to perennial organs.

It is believed that this remobilization of organic components in perennial organs happens more intensively, and as a natural process in lucerne, over the periods when temperature ranges between 6 and $18{ }^{\circ} \mathrm{C}$, from the end of winter to early spring in the Canterbury region. The low photoperiod in this season leads to temperature as the main control factor of this characteristic (Brown, Moot \& Teixeira, 2006; Teixeira, Moot \& Brown, 2008; Teixeira et al., 2011).

Based on this literature review, there is a demand to evaluate which lucerne dormancy level is appropriate to local environmental conditions, once both dormancy extremes have advantages and disadvantages. Whereas there is lower shoot yield, there is also higher survival or high shoot yield for one or two years with earlier reseeding. Likewise, there is the need to investigate the best defoliation management to be done to promote a greater shoot yield, nutritional quality, persistency and canopy efficiency in the long term.

\section{Conclusion}

The Brazilian conditions present the required environmental inputs to produce lucerne, as long photoperiod, rainfall and temperature. However, high costs of genetic researches and material importation; and improper management delayed the establishment of this species in this country. As a consequence, other legume species were established with lower nutritional quality, lower persistence or lower shoot yield, but adapted to the soil and management, as estilosantes (Stylosanthes) and guandu bean (Cajanus cajan) in West Central Region and fodder peanut (Arachis pintoi) in South Region.

This literature review showed that, in the close future, genetic research and institutes should focus on the efforts to increase lucerne crops in Brazil. It could improve the inoculating bacteria aluminium resistance and allow the cultivation of this species to optimize animal performance, nitrogen soil content, reduce the requirements of protein supplementation, and increase the producer profitability per area.

\section{Acknowledgments}

This study was financed in part by the Coordenação de Aperfeiçoamento de Pessoal de Nível Superior - Brasil (CAPES) - Finance Code 001, which supportted the first author to study at Lincoln University.

\section{References}

Avice, J. C. et al. (1996). Nitrogen and carbon flows estimates by $15 \mathrm{~N}$ e 13C pulse-chase labeling during regrowth of alfalfa. Plant physiology. 290, 112-281, https://www.ncbi.nlm.nih.gov/pmc/articles/PMC157947/pdf/1120281.pdf

Ávila, K. M. S. et al. (2019). Seleção de alfafa (Medicago sativa L.) para tolerância ao alumínio em solução nutritiva. Revista Brasileira de Agropecuária Sustentável, 9(1), 105-111. 10.21206/rbas.v9i1.6279

Baldissera, T. C. et al. (2014). Plant development controls leaf area expansion in alfalfa plants competing for light. Annals of Botany, 113, $145-157$. $10.1093 / \mathrm{aob} / \mathrm{mct} 251$

Barnes, D. K. et al. (1979). Fall dormancy in alfalfa: A valuable predictive tool. In: Barnes, D.K. (ed.) Report of the $26^{\text {th }}$ Alfalfa Improvement Conference, Brookings, South Dakota State University, SD.

Basigalup, D. H. \& Ustarroz, E. (2007). Grazing alfalfa systems in the Argentinean pampas. Proceedings..., Monterey, USA. https://alfalfa.ucdavis.edu/+symposium/proceedings/ 2007/07-51.pdf

Benzaghta, M. A. et al. (2021). Aplicações de análise SWOT: uma revisão integrativa da literatura. Journal of Global Business Insights, 6(1), 54-72. 10.5038/2640-6489.6.1.1148.

Berone, G. D., Sardiña, M. C. \& Moot, D. J. (2020). Animal and forage responses on lucerne (Medicago sativa L.) pastures under contrasting grazing managements in a temperate climate. Grass and Forage Science, 00, 1-14. 10.1111/gfs. 12479. 
Botrel, M. A. et al. (2001). Cultivares de alfafa em área de influência da Mata Atlântica no Estado de Minas Gerais. Pesquisa Agropecuária Brasileira, 36(11), 1437-1442. https://www.scielo.br/j/pab/a/Bf6FgFDJwRyMxZvLxgZCqTn/?lang=pt\&format=pdf

Bouton, J. H. (2012). Breeding lucerne for persistence. Crop and Pasture Science, 63(2), 95-106. 10.1071/CP12009

Brown, H. E., Moot, D. J. \& Pollock, K. M. (2005). Herbage production, persistence, nutritive characteristics and water use of perennial forages grown over 6 years on a Wakanui silt loam. New Zealand Journal of Agricultural Research, v.48, p.423-439. 10.1080/00288233.2005.9513677

Brown, H. E., Moot, D. J. \& Teixeira, E. I. (2006). Radiation use efficiency and biomass partitioning of lucerne (Medicago sativa L.) in a temperate climate. European Journal Agronomy, 25, 319-327. 10.1016/j.eja.2006.06.008.

Brummer, E. C., Shah, M. M. \& Luth, D. (2000) Reexamining the relationship between fall dormancy and winter hardiness in alfalfa. Crop Science, 40, 971977. 10.2135/cropsci2000.404971x.

Bummer, E. C. (2004). Genomic research in alfalfa, Medicago sativa L. In: Wilson, R.F., Stalker, H.T. \& Brummer, C.E. (Ed.). Legume Crop Genomics, AOCS Press, Champaign, Illinois, Chapter 7.

Chen, J. et al. (2013). Effects of cutting on alfalfa yield and quality in Northeast China. Journal of Animal and Veterinary Advances, 12(2), 253-26. https://www.cabdirect.org/ cabdirect/abstract/20133294145

Clark, S. G. et al. (2019). Maximizing lucerne (Medicago sativa L.) production with fixed-length recovery intervals after defoliation in mild winter environments. Journal of Agronomy and Crop Science, 205(1), 88-98. 10.1111/jac.12300

Costa, N. L. et al. (2011). Acúmulo de forragem e eficiência de utilização da radiação em pastagens de Axonopus aureus, durante o período seco, nos cerrados de Roraima. Revista Agro@mbiente On-line, 5(2), 143-147. https://www.alice.cnptia.embrapa.br/bitstream/doc/901802/1/548.pdf

Craig, P. R., Coventry, D. \& Edwards, J. H. (2013). Productivity advantage of crop-perennial pasture intercropping in Southern Australia. Agronomy, Soils and Environmental Quality, 105(6), 1588-1596. 10.2134/agronj2013.0196

Cunningham, S. M. \& Volenec, J. J. (1997). Seasonal carbohydrates and nitrogen metabolism in roots of contrasting alfalfa (Medicago sativa L.) cultivars Journal of Plant Physiology, 153(1-2), 220-225. 10.1016/S0176-1617(98)80069-2

Cunningham, S. M. et al. (2001). Winter hardiness, root physiology and gene expression in successive fall dormancy selection of "Mesilla" and "CUF 101" alfalfa. Crop Science, 41, 1091-1098. 10.2135/cropsci2001.4141091x.

Fédière, G. et al. (2003). Record of densoviral diseases occuring among the noctuid populations in lucerne field at El-Bahareya oasis in Egypt. In: Papierok, B. (ed.) (2003). Insect Pathogens and Insects Parasitic Nematodes, IOBC wprs Bulletin, Athens, Greece, 26(1), 237-240.

França, S. et al. (1997). Radiação fotossintéticamente ativa e sua relação com a radiação solar global em dossel de alfafa, em função do índice de área foliar. Revista Brasileira de Agrometeorologia, 5(2), 147-153. http://sbagro.org/files/biblioteca/132.pdf

García, L.A. et al. (2021). Dynamics of aerial and perennial biomass of two lucerne cultivars with different fall dormancies subjected to two severities of cutting during the establishment phase. Revista de la Facultad de Agronomía, 120(1), 1-10. 10.24215/16699513e072

Gastal, F. \& Lemaire, G. (2015). Defoliation, shoot plasticity, sward structure and herbage utilization in pasture: review of the underlying ecophysiological process. Agriculture, 5, 1146-1171. 0.3390/agriculture5041146

Gramshaw, D., Lowe, K. F. \& Lloyd, D. L. (1993). Effect of cutting interval and winter dormancy on yield, persistence, nitrogen concentration, and root reserves of irrigated lucerne in the Queensland subtropics. Australian Journal of Experimental Agriculture, 33, 847-854. 10.1071/EA9930847.

Haangerson, D. M., Cunningham, S. M. \& Volenec, J. J. (2003). Root physiology of less fall dormant, winter hardy alfalfa selections. Crop Science, 43, 14411447. $10.2135 /$ cropsci2003.1441.

Han, Q. et al. (2011). Characteristics of endogenous hormone variations in the roots of alfalfa (Medicago sativa L.) cultivars of different fall dormancy during spring regrowth stages. Agriculture Science in China, 10(7), 1032-1040. 10.1016/S1671-2927(11)60091-6

Harvey, B. M., Widdup, K. H. \& Barrett, B. A. (2014). An evaluation of lucerne for persistence under grazing in New Zealand. In: Proceedings of..., Alexandra, New Zealand. https://www.nzgajournal.org.nz/index.php/ProNZGA/article/view/2954

Hoppen, S. M. et al. (2019). Shoot and perennial organs yields of lucerne genotypes of three fall dormancy levels over five years. Proceedings of..., Wagga Wagga, Australia. http://agronomyaustraliaproceedings.org/images/sampledata/2019/2019ASA_Hoppen_Sarah_315.pdf

Jáuregui, J. M. et al. (2019). Yield components of lucerne were affected by sowing dates and inoculation treatments. European Journal of Agronomy, 103, 112. 10.1016/j.eja.2018.10.005

Kallembach, R. L., Nelson, C. J. \& Coutts, J. H. (2002). Yield, quality, and persistence of grazing- and hay-type alfalfa under three harvest frequency. Agronomy Journal, 94, 1094-1103. 10.2134/agronj2002.1094

Lemaire, G. \& Chapman, D. (1996). Tissue flows in grazed plant communities. In: Hodgson, J. \& Illius, A.W. (Eds.). The ecology and management of grazing systems, CABI, Wallingford, 3-36.

Lemaire, G., Durand, J. L. \& Lila, M. (1989). Effet de la sécheresse sur la valeur énergétiwue et azotée de la luzerne (Medicago sativa L.). Agronomie, 9(9), 841-848. https://hal.inrae.fr/hal-02726509

Lemaire, G. \& Agnusdei, M. (2000). Leaf tissue turnover and efficiency of herbage utilization. In: Lemaire, G. et al. (Eds.). Grassland Ecophysiology and Grazing Ecology, CABI Publishing, Wallingford, UK, 265-287. 
Lemaire, G. et al. (2019). Allometric approach to crop nutrition and implications for crop diagnosis and phenotyping. A review. Agronomy for Sustainable Development,39-27. 10.1007/s13593-019-0570-6

Li, X. et al. (2015). Mapping fall dormancy and winter injury in tetraploid alfalfa. Crop Science, 55, 1995-2011. 10.2135/cropsci2014.12.0834

Liang, S. et al. (2014). Incident Photosynthetic Active Radiation. In: Liang, S. et al. (Eds.). Global Land Surface Satellite (GLASS) Products. Springer, New York. 10.1007/978-3-319-02588-9_6.

Liu, Z. et al. (2016). Autumn dormancy regulates the expression of cas18, vsp and corF genes during cold acclimation of lucerne (Medicago sativa L.). Crop \& Pasture Science, 67, 666-678. 10.1071/CP15289

Luo, Y. Z. et al. (2019). Roots of lucerne seedlings are more resilient to water deficit than leaves and stems. Agronomy, 9, 123. 10.3390/agronomy9030123

Maamouri, A. et al. (2017). Performance of lucerne genotypes for biomass production and nitrogen content differs in monoculture and in mixture with grasses and is partially predicted from traits recorded on isolated plants. Crop \& Pasture Science, 68(11), 942-951. 10.1071/CP17052

Mattera, J. et al. (2013). Yield components, light interception and radiation use efficiency of Lucerne (Medicago sativa L.) in response to row spacing. European Journal of Agronomy, 45, 87-95. 10.1016/j.eja.2012.10.008

Mitchell, M. L. et al. (2020). Harvest initial affects lucerne (Medicago sativa L.) taproot total yield, starch, nitrogen and water-soluble carbohydrates. Journal of Agronomy, Crop Science, 0, 1-11. 10.1111/jac.12397

Moot, D. J., Teixeira, E. I. \& Brown, H. (2012). Alfalfa. In: Steduto, P., et al. (Eds.). Food and Agriculture Organization of the United Nations. Chapter 3, 212-219. Rome, Italy. https://www.fao.org/3/i2800e/i2800e.pdf

Moot, D. J. et al. (2021). Pasture resilience reflects differences in root and shoot responses to defoliation, and water and nitrogen deficits. Journal of New Zealand Grasslands, 17. 10.33584/rps.17.2021.3472

Moraes, A. \& Palhano, A. L. (2002). Fisiologia da produção de plantas forrageiras. In: Wachowicz, C. M. \& Carvalho, R. N. (Eds.). Fisiologia Vegetal -

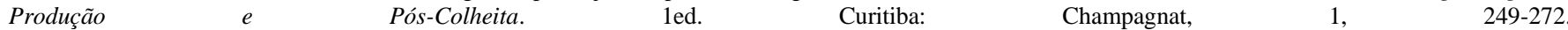
https://www.fcav.unesp.br/Home/departamentos/zootecnia/anaclaudiaruggieri/1.fisiologiaplantas_forrageiras.pdf

Pembletom, K. G., Cunningham, S. M. \& Volenec, J. J. (2010). Effects of summer irrigation on seasonal changes in taproot reserves and the expression of winter dormancy/activity in four contrasting lucerne cultivars. Crop \& Pasture Science, 61, 873-884, 10.1071/CP10030

Radcliffe, J. E. \& Baars, J. A. (1987). The productivity of temperate grasslands. In: Snaydon, R. W. (Eds). Ecosystems of the world. Elsevier Science Publishers, Amsterdam, Netherlands.

Radin, B. et al. (2003). Eficiência no uso de radiação fotossinteticamente ativa pela cultura do tomateiro em diferentes ambientes. Pesquisa Agropecuária Brasileira, 38(9), 1017-1023, 2003. 10.1590/S0100-204X2003000900001

Rassini, J. B. (1999). Alfafa (Medicago sativa L.): estabelecimento e cultivo no Estado de São Paulo. In: BARBOSA, R., et al. (Ed.). Utilização de forrageiras para intensificação da produção de carne e leite. Anais..., EMBRAPA - Pecuária Sudeste, São Carlos, São Paulo, 140. https://www.alice.cnptia.embrapa.br/bitstream/doc/44529/1/ PROCIJBR1999.00071.PDF

Rassini, J. B. et al. (2015). Manejo da forragem. In: Ferreira, R.P., et al. (Ed.). Cultivo e utilização de alfafa na alimentação de vacas leiteiras. EMBRAPA, Brasília, 47-51.

Rimi, F. et al. (2014). Fall dormancy and harvest stage impact on alfalfa persistence in a subtropical climate. Agronomy Journal, $106(4)$, $1258-1266$. 10.2134/agronj13.0495

Saibro, J. C. (1985). Produção de alfafa no Rio Grande do Sul. In: Simpósio sobre manejo de pastagem. Anais..., Piracicaba: FEALQ, 61-106.

Seppänen, M. M. et al. (2018). Growth, freezing tolerance, and yield performance of alfalfa (Medicago sativa L.) cultivars grown under controlled and field conditions in northern latitudes. Canadian Journal of Plant Science, 98, 1109-1118. 10.1139/cjps-2017-0305

Ta, H., Teixeira, E. I. \& Moot, D. J. (2016). Impact of autumn (fall) dormancy rating on growth and development of seedling Lucerne. Journal of New Zealand Grasslands, 78, 169-176. http://dspace.lincoln.ac.nz/handle/10182/11511

Ta, H. et al. (2020). Yield and quality changes in lucerne of different fall dormancy rates under three defoliation regimes. European Journal of Agronomy, 115. 10.1016/j.eja.2020.126012

Tabacco, E. et al. (2002). Effect of cutting frequency on dry matter yield and quality of lucerne (Medicago sativa L.) in the Po Valley. Italian Journal of Agronomy, 6(1), 27-33. https://agris.fao.org/agris-search/search.do?recordID=IT2003063362

Teixeira, E. I. et al. (2007a). The dynamics of lucerne (Medicago sativa L.) yields components in response to defoliation frequency. European Journal of Agronomy, 26, 394-400. 10.1016/j.eja.2006.12.005

Teixeira, E. I. et al. (2007b). How does defoliation management impact on yield, canopy forming process and light interception of lucerne (Medicago sativa L.) crops? European Journal of Agronomy, 27, 154-164. 10.1016/j.eja.2007.03.001

Teixeira, E. I., Moot, D. J. \& Mickelbart, M. V. (2007). Seasonal patterns of root C and N reserves of lucerne crops (Medicago sativa L.) grown in a temperate climate were affected by defoliation regimes. European Journal of Agronomy, 26, 10-20. 10.1016/j.eja.2006.08.010 
Research, Society and Development, v. 11, n. 1, e11711124473, 2021

(CC BY 4.0) | ISSN 2525-3409 | DOI: http://dx.doi.org/10.33448/rsd-v11i1.24473

Teixeira, E. I., Moot, D. J. \& Brown, H. E. (2008). Defoliation frequency and season affected use radiation efficiency and dry matter partitioning to roots of lucerne (Medicago sativa L.) crops. European Journal of Agronomy, 28(2), 103-111. 10.1016/j.eja.2007.05.004

Teixeira, E. I. et al. (2011). Growth and phonological development patterns differ between seedling and regrowth lucerne crop (Medicago sativa L.). European Journal of Agronomy, 35, 47-55. 10.1016/j.eja.2011.03.006

Ventroni, L. M., Volenec, J. J. \& Cangiano, C. A. (2010). Fall dormancy and cutting frequency impact on alfalfa yield and yields components. Field Crop Research, 119, 252-259. 10.1016/j.fcr.2010.07.015

Veronesi, F., Brummer, E. C. \& Huyghe, C. (2010). Alfalfa. In: Boller, B., Posselt, U. K. \& Veronesi, F. (Eds.). Fodder crops and amenity grasses, Handbook of Plant Breeding, 5, Springer, New York. 10.1007/978-1-4419-0760-8_17

Vilela, D. et al. (2008). Prioridades de pesquisa e futuro da alfafa no Brasil. In: FERREIRA, R. D. P. et al (Ed.). Cultivo e utilização de alfafa nos trópicos, São Carlos: EMBRAPA Pecuária Sudeste, 489 p. https://www.alice.cnptia.embrapa.br/bitstream/doc/47404/4/PROCIRPF2008.00235.pdf

Wang, C. et al. (2009). Yields of alfalfa varieties with different fall-dormancy levels in temperate environment. Agronomy Journal, 101(5), 1146-1152. 10.2134/agronj2009.0026

Weller, D. E. (1987). Self-thinning exponent correlated allometric measures of plant geometry. Ecology, 68(4), 813-821. 10.2307/1938352

$\mathrm{Xu}, \mathrm{H}$. et al. (2020). Metabolomic analyses reveal substances that contribute to the increased freenzing tolerance of alfalfa (Medicago sativa L.) after continuous water deficit. BMC Plant Biology, 20(15). 10.1186/s12870-019-2233-9

Yang, X. (2020). Modelling phenological development, yield and quality of lucerne (Medicago sativa L.) using APSIM next generation. A thesis submitted in partial fulfillment of the requirement for the Degree of Doctor of Philosophy at Lincoln University, 323p. https://researcharchive.lincoln.ac.nz/handle/10182/13956

Yang, X. et al. (2021). Development of lucerne model in APSIM next generation: 1 phenology and morphology of genotypes with different fall dormancies. European Journal of Agronomy, 130, 126372. 10.1016/j.eja.2021.126372

Yoda, K. (1963). Self-thinning in overcrowded pure stands under cultivate or natural conditions (Intraspecific competitions among higher plants). Journal of the Institute Polytechnic of Osaka, 14, 107-129. https://ci.nii.ac.jp/naid/10030417634/ 